\title{
Effect of long-chain inorganic polyphosphate treated with wheat phytase on interleukin 8 signaling in HT-29 cells
}

\author{
Jeongmin $\mathrm{An}^{1}$ and Jaiesoon $\mathrm{Cho}^{1, *}$
}

* Corresponding Author: Jaiesoon Cho Tel: +82-2-450-3375, Fax: +82-2-455-1044,

E-mail: chojs70@konkuk.ac.kr

1 Department of Animal Science and Technology, Konkuk University, Seoul 05029,

Korea

ORCID

Jeongmin An

https://orcid.org/0000-0002-2357-0941

Jaiesoon Cho

https://orcid.org/0000-0002-4511-8032

Submitted Sept 24, 2021; Revised Nov 26, 2021; Accepted Dec 14, 2021
Objective: This study was performed to investigate the potential effect of wheat phytase on long-chain inorganic polyphosphate (polyP)-mediated interleukin 8 (IL-8) signaling in an intestinal epithelial cell line, HT-29 cells.

Methods: Cell viability and the release of the pro-inflammatory cytokine IL-8 in HT-29 cells exposed to polyP1150 (average of 1,150 phosphate residues) treated with or without wheat phytase were measured by the EZ-CYTOX kit and the IL-8 ELISA kit, respectively. Also, the activation of cellular inflammatory factors NF- $\kappa B$ and MAPK (p38 and ERK 1/2) in HT-29 cells was investigated using ELISA kits.

Results: PolyP1150 negatively affected the viability of HT-29 cells in a dose-dependent manner. However, $100 \mathrm{mM}$ polyP1150 dephosphorylated by wheat phytase increased cell viability by 1.4 -fold over that of the intact substrate. Moreover, the $24 \mathrm{~h}$ exposure of cells to enzyme-treated $50 \mathrm{mM}$ polyP1150 reduced the secretion of IL- 8 and the activation of NF$\kappa \mathrm{B}$ by $9 \%$ and $19 \%$, respectively, compared to the intact substrate. PolyP1150 (25 and 50 $\mathrm{mM}$ ) dephosphorylated by the enzyme induced the activation of p38 MAPK via phosphorylation to 2.3 and 1.4-fold, respectively, compared to intact substrate, even though it had little effect on the expression of ERK 1/2 via phosphorylation.

Conclusion: Wheat phytase could attenuate polyP1150-induced IL-8 release in HT-29 cells through NF- $\kappa B$, independent of MAP kinases p38 and ERK. Thus, wheat phytase may alleviate inflammatory responses including hypercytokinemia caused by bacterial polyP infection in animals. Therefore, wheat phytase has the potential as an anti-inflammatory therapeutic supplement in animal husbandry.

Keywords: HT-29; Inflammatory Responses; Long-chain Inorganic Polyphosphate; Wheat Phytase

\section{INTRODUCTION}

Inorganic polyphosphate (polyP), a linear physiological polymer formed by structurally simple phosphoanhydride linkages, is largely categorized into short-chain polyP with fewer than 100 phosphate residues and long-chain polyP with up to about 1,000 phosphate residues $[1,2]$. Recently, the latter was reported to be responsible for the virulence of some bacteria. Campylobacter jejuni, a harmful food-poisoning bacteria in the poultry industry synthesized polyP through polyP kinase (PPK) and accumulated it within the polyP granules $[1,3]$. When bacterial infections occur in animals, polyP is released from the granules and acts as a chemotactic agent for immune cells $[3,4]$. In addition, polyP over-promotes macrophage differentiation to destroy the immunity of the host and induce strong inflammatory diseases [5,6]. In some studies, polyP upregulated the cytokine interleukin 11 (IL-11) in human osteosarcoma SaOS-2 cells and PPK stimulated the secretion of a well-known inflammatory response mediator interleukin 8 (IL-8) in human embryonic intestine INT407 
cells $[7,8]$. Short-chain polyP induced a pro-inflammatory signaling response in human monocytic leukemia cells (THP-1) and primary human umbilical vein endothelial cells (HUVEC) by activating nuclear factor kappa-light-chainenhancer of activated B cells (NF- $\mathrm{BB}$ ) involved in various immune responses $[9,10]$. Many studies have reported that NF- $\kappa B$ was essential for the expression of IL- 8 in various cells $[11,12]$. In addition, short-chain polyP could stimulate the activation of NF- $\mathrm{KB}$ and ERK and the production of IL-6 and TNF- $\alpha$ [13]. Many factors like bacterial polyPs and cellular regulators stimulate the activation of NF- $\mathrm{kB}$, the main immune-related transcription factor $[14,15]$. ERK and p38, members of mitogen-activated protein kinase (MAPK), can affect NF- $\kappa B$ activation, which leads to interaction with diverse pro-inflammatory genes and facilitates gene expression [15]. In this study, long-chain polyP mainly released from bacteria stimulated NF- $\mathrm{\kappa B}$ activity and induced IL-8 secretion, resulting in severe inflammatory symptoms such as diarrhea and fever in the host animals $[16,17]$. This eventually can bring huge commercial losses in animal husbandry [17].

The number of scientific reports on plant phytases showing the significant potential of feed supplements has increased considerably [18]. Wheat phytase, known as an unusual multiple inositol phosphate phosphatase possesses different phytate hydrolysis properties compared to fungal histidine acid phosphatase, the main constituent of commercial feed phytases [19]. Furthermore, wheat phytase non-specifically dephosphorylates long-chain polyP, which is essential to maintaining the pathogenicity of C. jejuni, Escherichia coli, and Salmonella enterica serovar typhimurium, the major causes of bacterialborne diseases in animal husbandry [20].

Our hypothesis was that the dephosphorylation of longchain polyP by wheat phytase may affect the expression of NF- $\kappa B$ and IL- 8 associated with the inflammatory responses of the host cells, and that wheat phytase may increase cell viability by regulating hypercytokinemia in the cells. The mechanism of polyP-induced inflammation is still poorly understood. However, most of the studies have focused on short-chain polyP. The objective of the current study was to investigate the potential effect of wheat phytase on long-chain polyP-mediated IL-8 signaling in the intestinal epithelial cell line, HT-29.

\section{MATERIALS AND METHODS}

\section{Reagents and cell culture}

PolyP1150 with an average of 1,150 inorganic phosphate residues and wheat phytase were purchased from Kerafast (Boston, MA, USA) and Sigma-Aldrich (St. Louis, MO, USA), respectively. Both were reconstituted in endotoxin-free water (Sigma-Aldrich, USA). The human colorectal adenocarcinoma cell line, HT-29 was purchased from the American Type Culture Collection (ATCC, Manassas, VA, USA). The cells were grown in McCoy's 5A medium (Gibco Life Technologies, Waltham, MA, USA) containing 10\% fetal bovine serum and $1 \%$ penicillin-streptomycin solution (Gibco Life Technologies, USA). Cell cultures were maintained at $37^{\circ} \mathrm{C}$ in a humidified incubator with $95 \%$ air and $5 \% \mathrm{CO}_{2}$.

\section{Cell viability assay}

HT-29 cells were initially seeded onto a 96-well plate at a concentration of $2 \times 10^{4}$ cells per well and cultured until $80 \%$ confluency. Different concentrations of polyP1150 (0, 10, 25, $50,100,200$, and $400 \mathrm{mM}$ ) were added to the cells at $37^{\circ} \mathrm{C}$ for $48 \mathrm{~h}$ in a $\mathrm{CO}_{2}$ incubator. The cell viability was measured at optical density (OD) $450 \mathrm{~nm}$ using an EZ-CYTOX kit (DogenBio, Seoul, Korea) according to the manufacturer's instructions.

\section{Effect of wheat phytase on cell viability}

HT-29 cells were seeded onto a 96-well plate and cultured until $80 \%$ confluency. PolyP1150 (500 and 1,000 mM) was incubated at $37^{\circ} \mathrm{C}$ for $4 \mathrm{~h}$ with or without wheat phytase $(42.9 \mathrm{mU} / \mathrm{mL})$. After the incubation, the cells were treated with aliquots $(10 \mu \mathrm{L})$ of the reaction mixtures at final concentrations of 50 and $100 \mathrm{mM}$ polyP1150 at $37^{\circ} \mathrm{C}$ for $24 \mathrm{~h}$ in the $\mathrm{CO}_{2}$ incubator. Cell viability was analyzed at $\mathrm{OD} 450 \mathrm{~nm}$ using an EZ-CYTOX kit (DogenBio, Seoul, Korea).

\section{IL-8 assay}

HT-29 cells were initially seeded onto 96-well plates and cultured until 80\% confluency. PolyP1150 (10, 50, 250, and 500 $\mathrm{mM}$ ) were treated at $37^{\circ} \mathrm{C}$ for $4 \mathrm{~h}$ with or without enzyme $(42.9 \mathrm{mU} / \mathrm{mL})$. After the incubation, aliquots $(10 \mu \mathrm{L})$ of the reaction mixtures were added to the cells at final concentrations of $1,5,25$, and $50 \mathrm{mM}$ polyP1150 at $37^{\circ} \mathrm{C}$ for $6 \mathrm{~h}$ in a $\mathrm{CO}_{2}$ incubator. In addition, the cells were exposed to $50 \mathrm{mM}$ polyP1150 with or without wheat phytase at $37^{\circ} \mathrm{C}$ for 1,6 , 12 , and $24 \mathrm{~h}$ in a $\mathrm{CO}_{2}$ incubator. The levels of IL-8 secreted into the cell culture media were evaluated at OD $450 \mathrm{~nm}$ using a Cymax human IL-8 ELISA kit (Ab FRONTIER, Seoul, Korea) according to the manufacturer's instructions.

\section{NF- $\mathrm{kB}$ assay}

HT-29 cells were seeded onto a 96-well plate and cultured until $80 \%$ confluency. And we incubated polyP 1150 at $37^{\circ} \mathrm{C}$ for $4 \mathrm{~h}$ with or without wheat enzyme $(42.9 \mathrm{mU} / \mathrm{mL})$. Aliquots $(10 \mu \mathrm{L})$ of the reaction mixtures containing different concentrations of polyP1150 (10, 50, 250, and $500 \mathrm{mM})$ were added to the cells at final concentrations of $1,5,25$, and 50 $\mathrm{mM}$ polyP 1150 at $37^{\circ} \mathrm{C}$ for $6 \mathrm{~h}$ in a $\mathrm{CO}_{2}$ incubator. The cells were also exposed to $50 \mathrm{mM}$ polyP1150 with or without wheat phytase at $37^{\circ} \mathrm{C}$ for $1,6,12$, and $24 \mathrm{~h}$ in a $\mathrm{CO}_{2}$ incubator. Total 
human NF- $\kappa B$ p65 levels in the HT-29 cell lysates were measured at OD $450 \mathrm{~nm}$ using an NF-kB p65 (Total) InstantOne ELISA kit (Thermo Fisher Scientific, Waltham, MA, USA) according to the manufacturer's instructions.

\section{p38 MAPK and ERK1/2 assay}

HT-29 cells were seeded onto a 96-well plate and cultured until $80 \%$ confluency. Different concentrations of polyP1150 $(10,50,250$, and $500 \mathrm{mM})$, were incubated at $37^{\circ} \mathrm{C}$ for $4 \mathrm{~h}$ with or without phytase $(42.9 \mathrm{mU} / \mathrm{mL})$. Aliquots $(10 \mu \mathrm{L})$ of the reaction mixtures were added to the HT-29 cells at final concentrations of $1,5,25$, and $50 \mathrm{mM}$ polyP 1150 at $37^{\circ} \mathrm{C}$ for $6 \mathrm{~h}$ and incubated. The cells were also exposed to $50 \mathrm{mM}$ polyP1150 with or without wheat phytase at $37^{\circ} \mathrm{C}$ for 1,6 , 12 , and $24 \mathrm{~h}$ in a $\mathrm{CO}_{2}$ incubator. The activity of total and phospho p38 in the HT-29 cells was measured at OD 450 nm using the p38 (Total/Phospho) InstantOne ELISA kit (Thermo Fisher Scientific, USA), and the amount of total and phospho ERK $1 / 2$ in the HT-29 cells was evaluated at OD $450 \mathrm{~nm}$ using the ERK 1/2 (Total/Phospho) InstantOne ELISA kit (Thermo Fisher Scientific, USA) according to the manufacturer's instructions.

\section{Statistical analysis}

Statistical significance between the groups was determined by a one-way analysis of variance with PROC general linear model (SAS 9.4, SAS Institute Inc, Cary, NC, USA) followed by Duncan's multiple range test. The probability levels used for statistical significance were $\mathrm{p}<0.05$. The results are expressed as the mean and standard error from three experiments.

\section{RESULTS}

\section{Cell viability following polyP1150 treatment}

As shown in Figure 1, polyP1150 negatively affected the viability of HT-29 cells in a dose-dependent manner. In particular, there was a drastic change in cell viability between $50 \mathrm{mM}$ and $100 \mathrm{mM}$ substrate concentrations. At $50 \mathrm{mM}$, the cells retained $83 \%$ of the initial viability. However, the cell viability was severely decreased to $50 \%$ at $100 \mathrm{mM}$.

\section{Altered cell viability by polyP1150 treated with wheat phytase \\ To some extent, polyP1150 dephosphorylated by wheat phy- tase alleviated the decrease in cell viability compared to intact polyP (Figure 2). In addition, $100 \mathrm{mM}$ polyP1150 treated with the enzyme increased the cell viability by 1.4 -fold over that of the intact substrate.}

Effect of long-chain inorganic polyphosphate added with wheat phytase on the release of IL-8 in HT-29 cells PolyP1150 failed to promote IL-8 secretion in HT-29 cells at

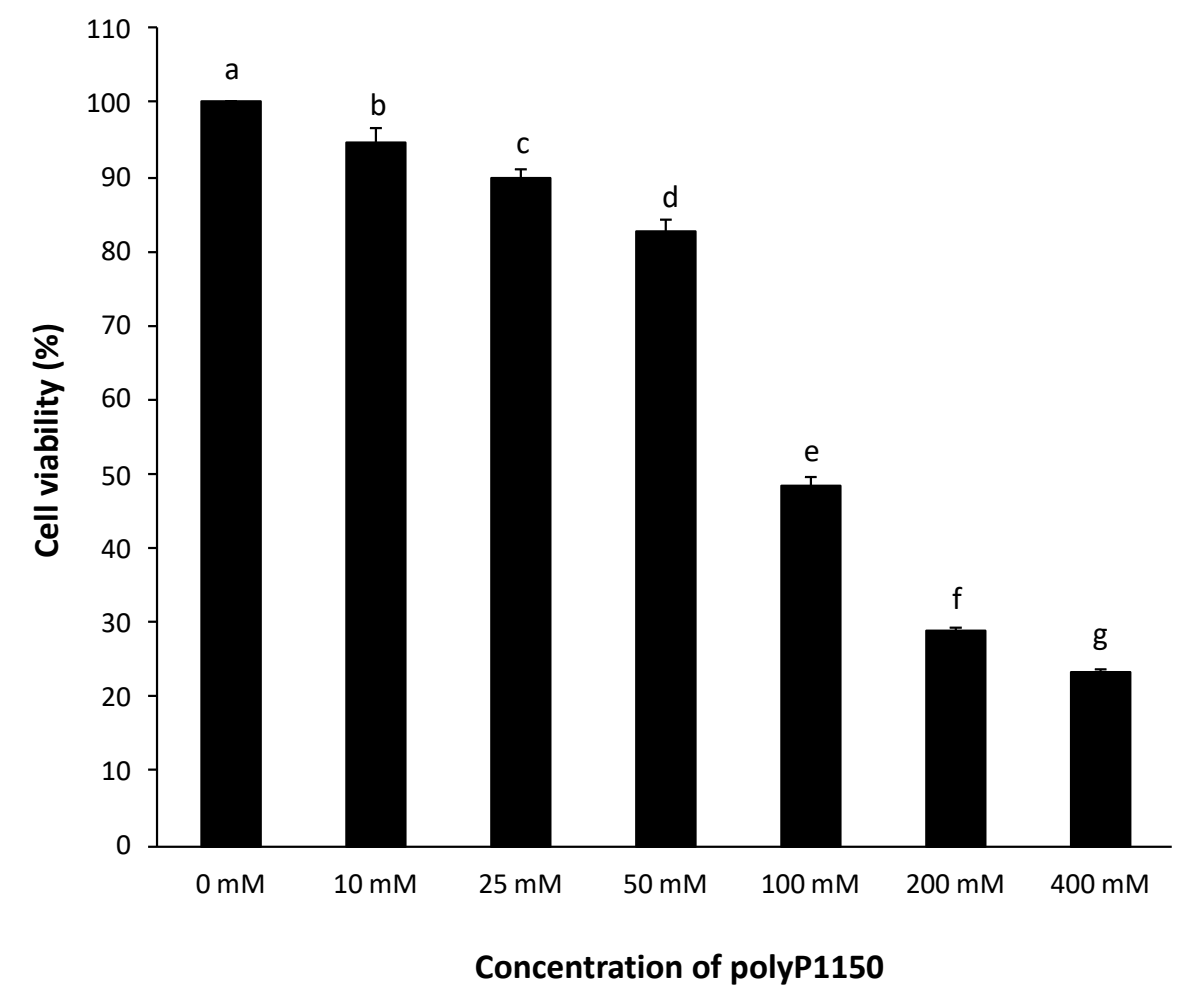

Figure 1. Cell viability of HT-29 cells exposed to long-chain inorganic polyphosphates. Data were expressed as mean and standard errors from three experiments. ${ }^{a-9}$ Means lacking common superscripts differ significantly $(p<0.05)$. 


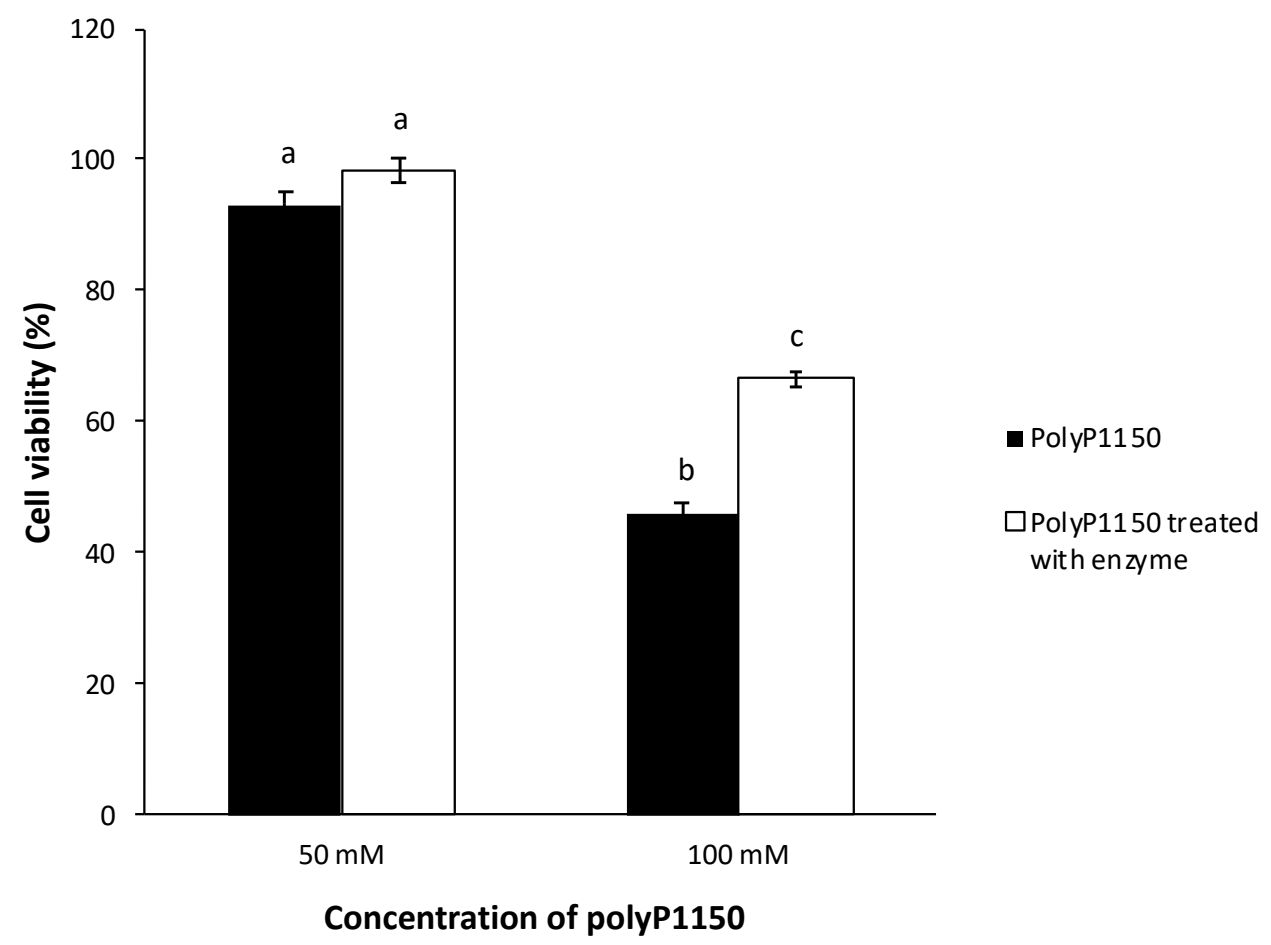

Figure 2. Cell viability of HT-29 cells exposed to long-chain inorganic polyphosphates treated with wheat phytase. Data were presented as mean and standard errors from three experiments. ${ }^{a-c}$ Means lacking common superscripts differ significantly $(p<0.05)$.

a low concentration of $1 \mathrm{mM}$, and there was no effect of wheat phytase (Figure 3a). However, at 5, 25, and $50 \mathrm{mM}$, polyP1150 promoted IL-8 secretion from HT-29 cells to approximately $146 \%, 132 \%$, and $183 \%$, respectively, compared to unstimulated controls. In contrast, phytase-treated polyP1150 showed a tendency to decrease IL-8 release from HT-29 cells at 5 and $25 \mathrm{mM}$ polyP1150 compared to intact polyp1150. Moreover, at $24 \mathrm{~h}$ exposure, $50 \mathrm{mM}$ polyP1150 dephosphorylated by wheat phytase reduced the secretion of IL-8 from HT-29 cells by $9 \%$ compared to the intact substrate (Figure $3 b$ ).

\section{Effect of long-chain inorganic polyphosphate added} with wheat phytase on the activation of NF-kB in HT-29 cells

A concentration of $50 \mathrm{mM}$ polyP1150 enhanced the activation of NF- $\kappa$ B in HT- 29 cells the most, by about $151 \%$ over that of unstimulated cells (Figure 4a). However, polyP1150 hydrolyzed by wheat phytase showed a tendency to reduce NF- $\kappa B$ activation in HT-29 cells compared to that of intact polyP1150. In addition, the activation of NF- $\mathrm{kB}$ was decreased by approximately $45 \%$ after exposure to wheat phytase-treated $25 \mathrm{mM}$ polyP1150 compared to the intact substrate. As shown in Figure 4b, intact polyP1150 upregulated the activation of NF- $\kappa \mathrm{B}$ in the cells in a time-dependent manner compared to unstimulated controls. However, $24 \mathrm{~h}$ exposure of cells to enzyme-treated polyP1150 reduced the activation of NF- $\mathrm{KB}$ by approximately $19 \%$ compared to cells treated with intact
polyP1150.

Effect of long-chain inorganic polyphosphate added with wheat phytase on the activation of p38 MAPK in HT-29 cells

The total p38 MAPK levels were very low, whether the cells were exposed to polyP1150 or enzyme-treated substrate. However, 25 and $50 \mathrm{mM}$ polyP1150 dephosphorylated by the enzyme induced the activation of p38 MAPK via phosphorylation 2.3 and 1.4-fold, respectively, compared to the intact substrates (Figure 5a). In addition, the phosphorylation of p38 MAPK was highest at $1 \mathrm{~h}$ exposure to $50 \mathrm{mM}$ polyP1150 treated with the enzyme (Figure 5b).

Effect of long-chain inorganic polyphosphate added with wheat phytase on the activation of ERK 1/2 in HT29 cells

As shown in Figures $6 \mathrm{a}$ and b, polyP1150 and wheat phytasetreated polyP1150 had little effect on the expression of ERK $1 / 2$ via phosphorylation in HT-29 cells. However, 25 and 50 $\mathrm{mM}$ enzyme-treated polyP1150 increased the expression of total ERK $1 / 2$ to 1.3 and 1.2-fold, respectively, compared to intact substrates. In addition, as HT-29 cells were exposed to $50 \mathrm{mM}$ intact polyP1150 and enzyme-treated polyP1150 longer, the expression of total ERK 1/2 showed a tendency to decrease (Figure 6b). 
(a)

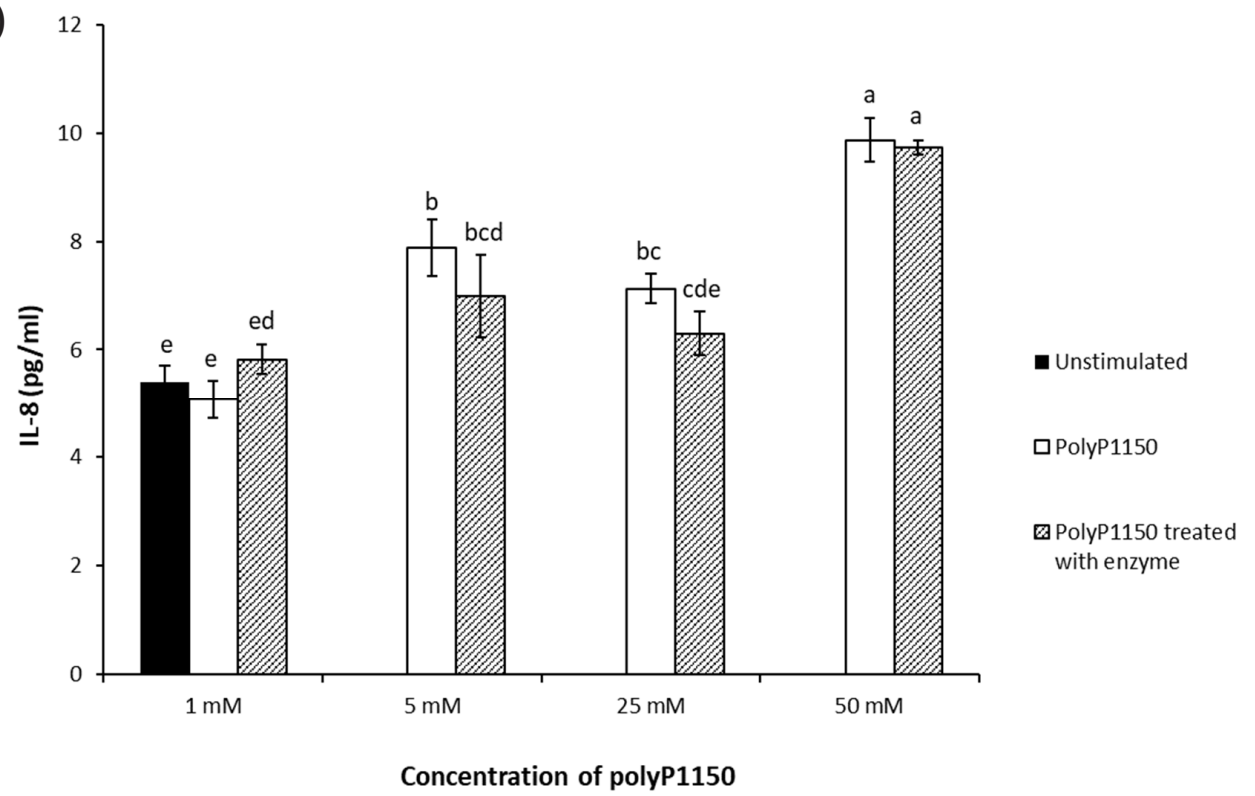

(b)

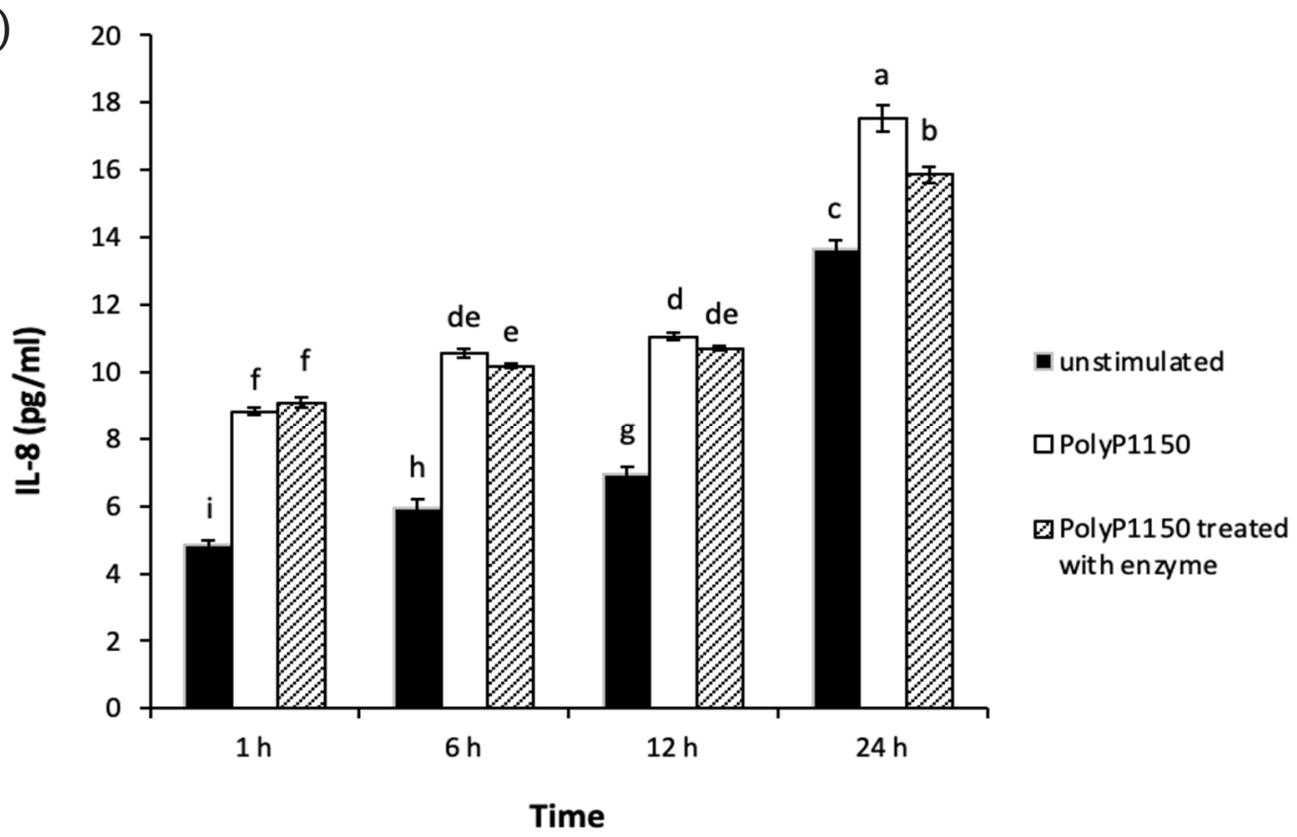

Figure 3. (a) Effect of various concentrations of long-chain inorganic polyphosphates treated with wheat phytase on interleukin 8 (IL-8) release in HT-29 cells. (b) Effect of long-chain inorganic polyphosphate $(50 \mathrm{mM})$ treated with wheat phytase for different times on IL-8 release in HT-29 cells. Data were presented as mean and standard errors from three experiments. ${ }^{a-i}$ Means lacking common superscripts differ significantly $(p<0.05)$.

\section{DISCUSSION}

Inorganic polyphosphate existing within bacteria is released into animal cells and induces various mechanisms related to excessive inflammation [4]. Therefore, an inhibitor of poly $\mathrm{P}$ has the potential to be an anti-inflammatory agent [21]. However, because of the structural characteristics of polyP, antipolyphosphate agents that inhibit polyP are not easily found [21].

In this study, pathogen-derived long-chain polyP1150 re- duced the viability of HT-29 cells by more than $50 \%$ at 100 $\mathrm{mM}$, indicating a fatal effect on the viability of HT-29 cells. PolyP, as an inflammatory material, reduced cell viability depending upon its concentration. And, polyP promoted the secretion of cytokines IL-11 and IL-8 [7]. But, the viability of HT-29 cells was increased after the application of wheat phytase to polyP1150, which was then used to treat the cells. Furthermore, polyP1150 that had been dephosphorylated by wheat phytase was less effective than intact polyP1150 at stimulating the secretion of the cytokine IL- 8 in HT-29 cells. 
(a)

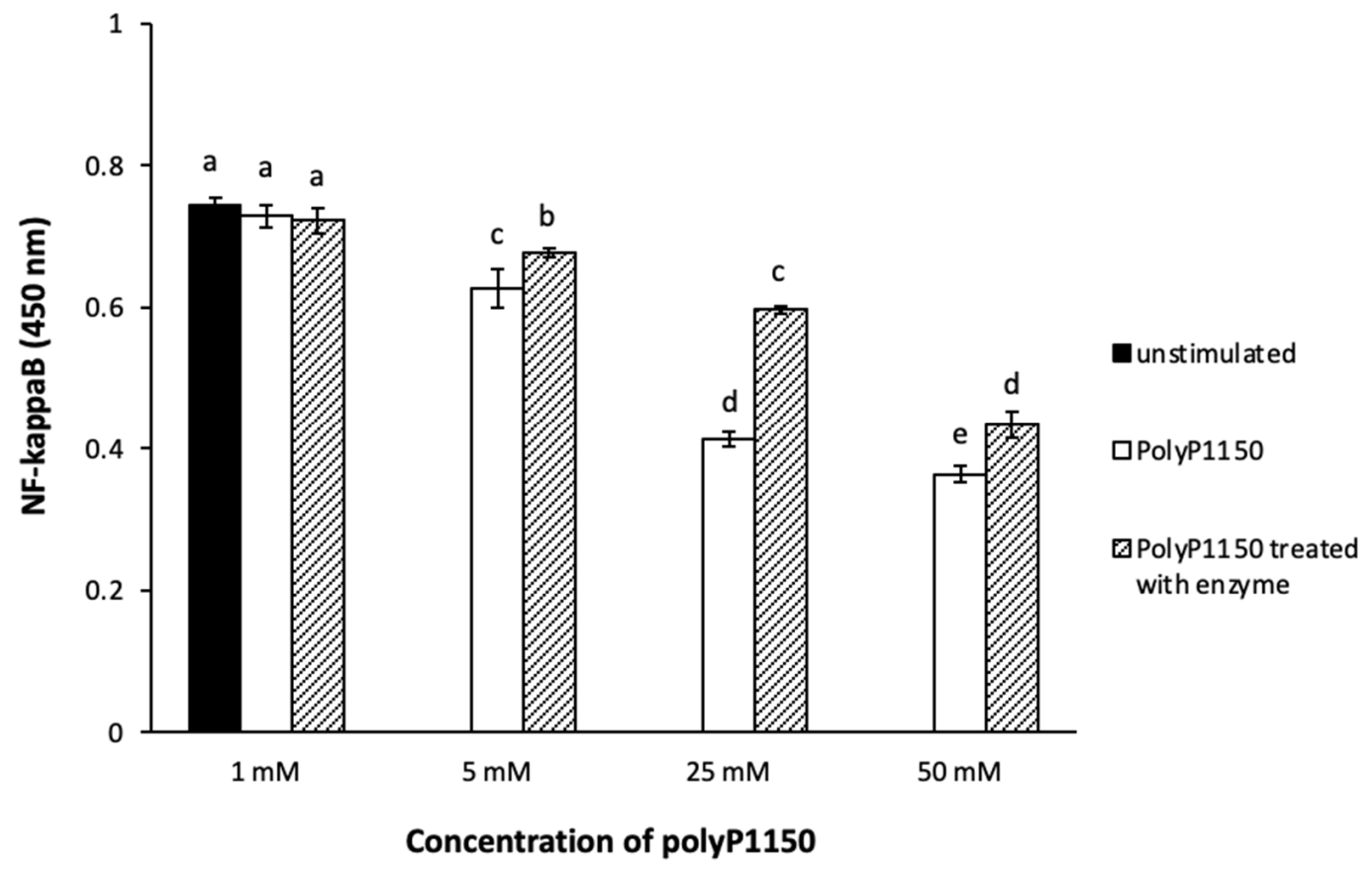

(b)

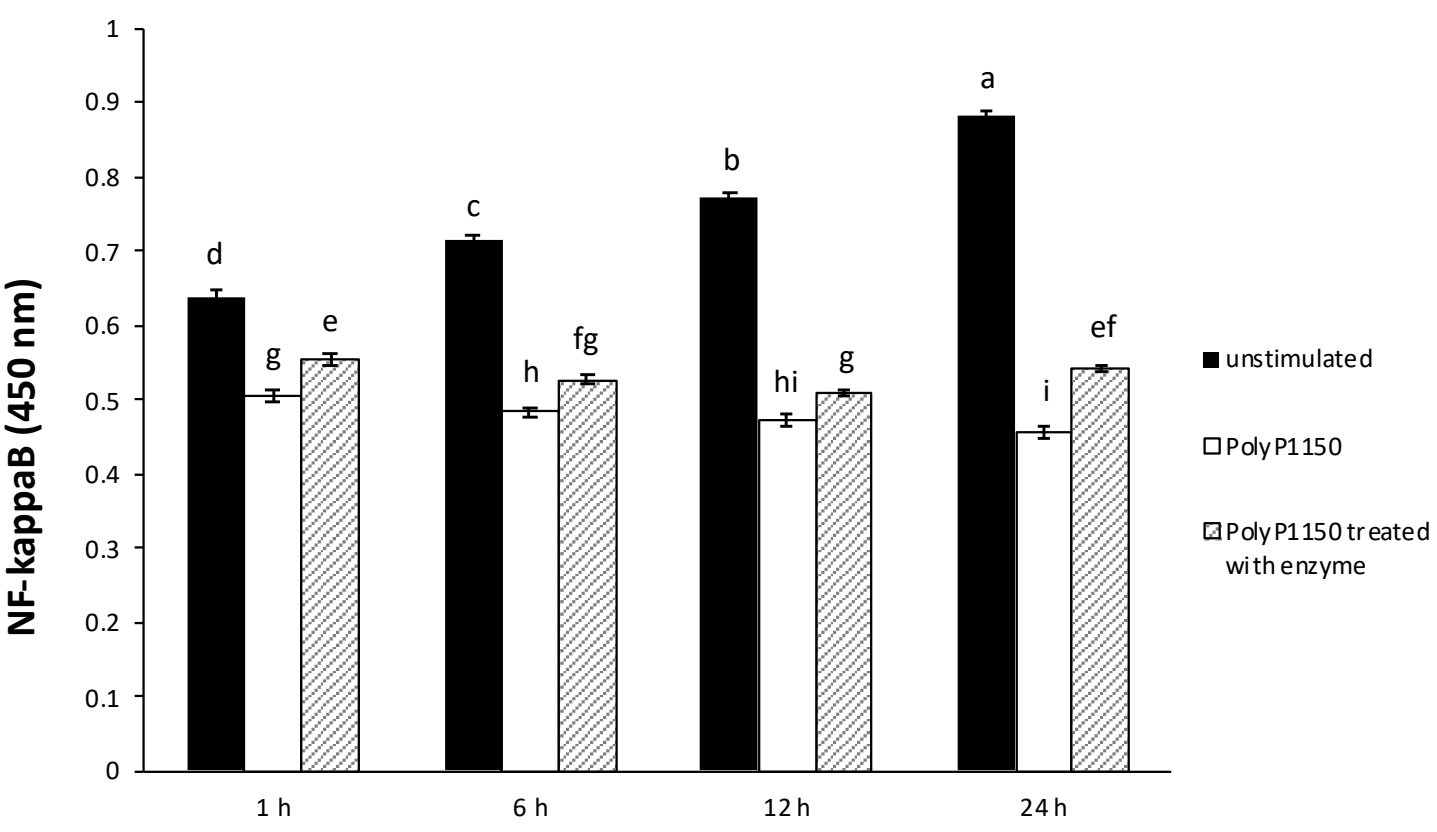

Time

Figure 4. (a) Effect of various concentrations of long-chain inorganic polyphosphates treated with wheat phytase on nuclear factor kappa-light-chain-enhancer of activated B (NF-kB) activation in HT-29 cells. (b) Effect of long-chain inorganic polyphosphate (50 mM) treated with wheat phytase for different times on NF-kB activation in HT-29 cells. Data were presented as mean and standard errors from three experiments. ${ }^{\text {a-i }}$ Means lacking common superscripts differ significantly $(p<0.05)$.

Indeed, polyP-mediated pro-inflammatory responses such as increased cytokine release were inhibited by the natural anticoagulant protease activated protein C (APC) in endothelial cells [9]. In this regard, wheat phytase alleviated the cytokine (IL-8) secretion induced by polyP in human epithelial cells and thus, has the potential to act as an anti-inflammatory enzyme like APC.

A number of previous studies showed that the activation of NF- $\kappa \mathrm{B}$ was essential for IL- 8 and the expression of many other pro-inflammatory genes $[11,12]$. NF- $\kappa B$ stimulates the expression of the IL- 8 gene and immunoglobulin receptor in human amnion/cervical epithelial cells and HT-29 cells, re- 
Total

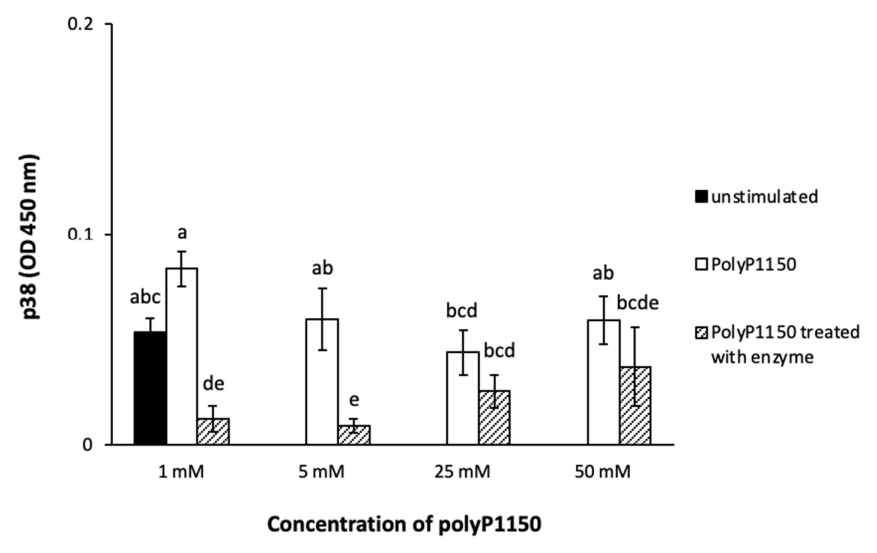

(a)
Total

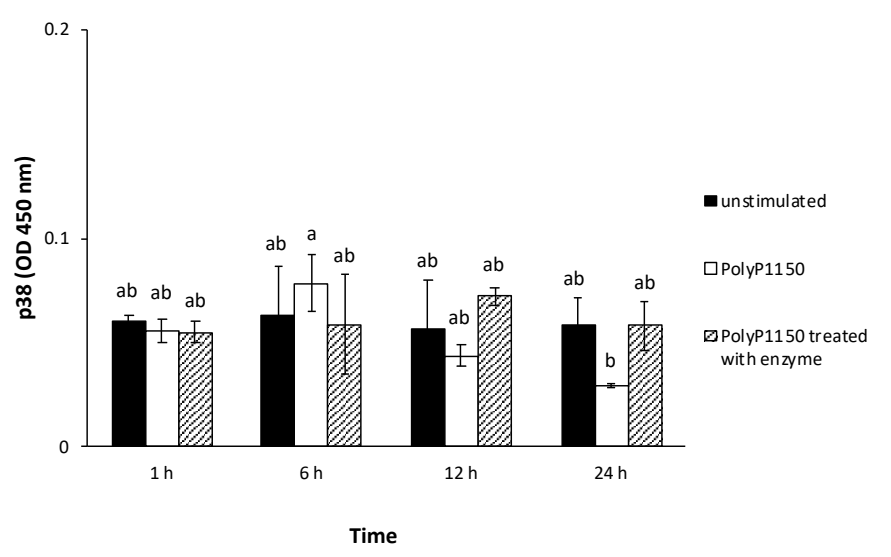

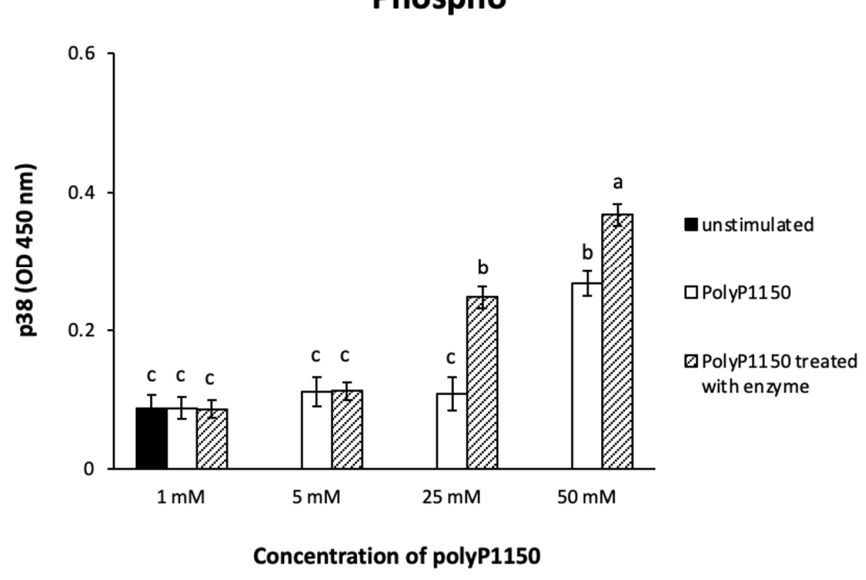

Phospho

Phospho

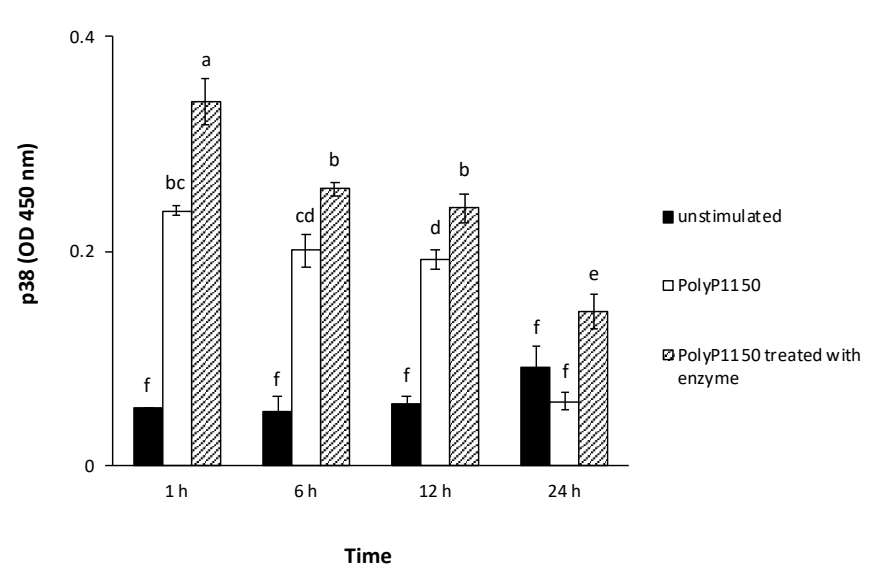

(b)

Figure 5. (a) Effect of various concentrations of long-chain inorganic polyphosphates treated with wheat phytase on total/phospho p38 activity in HT-29 cells. (b) Effect of long-chain inorganic polyphosphate $(50 \mathrm{mM})$ treated with wheat phytase for different times on total/phospho p38 activity in HT-29 cells. Data were presented as mean and standard errors from three experiments. ${ }^{\text {aff }}$ Means lacking common superscripts differ significantly $(p<0.05)$.

spectively [12]. Also, sphingosine 1-phosphate induced IL-8 release mediated by NF- $\mathrm{kB}$ from airway epithelial cells [22]. In unstimulated cells, NF- $\kappa B$ is found in the cytoplasm as $\mathrm{NF}-\mathrm{kB}$ is combined with inhibitory IkB proteins. Then, when the cells are stimulated and NF- $\kappa B$ is activated, NF- $\kappa B$ is released from the inhibitory protein and translocates to the nucleus where it activates transcription [23]. Some studies reported that polyP consisting of 45,65 , and 70 phosphate units activated NF- $\kappa B$ and elicited pro-inflammatory responses in human umbilical vein endothelial cells $[9,10]$. And the results obtained in our study revealed that like shortchain polyP (polyP45, 65, and 70), polyP1150 also stimulated $\mathrm{NF}-\kappa \mathrm{B}$ activation in the cells. After activation, NF- $\kappa \mathrm{B}$ promoted inflammatory diseases in human intestinal epithelial cells [24]. According to a previous study, these inflammatory responses were alleviated by the adenosine A3 receptor through inhibition of the NF- $\mathrm{kB}$ signaling pathway in HT-29 cells [25]. Presumably, wheat phytase changed the mechanism of action of polyP on the HT-29 cells through the hydrolysis of polyP and attenuated the activation of NF- $\mathrm{\kappa B}$ in HT-29 cells. And this change may have led to the decrease in cytokine (IL-8) release. The expression of IL-8 through the NF$\kappa \mathrm{B}$ pathway was mediated by $\mathrm{p} 38$ and ERK (MAPK) signaling in U937 cells [26]. Some studies have also indicated that MAPK transcription and NF- $\mathrm{B}$ activation stimulated IL-8 release [15]. ERK, an atypical MAPK, interacts with c-JUN proteins and plays a critical role in AP- 1 signaling that regulates the production of IL-8 [27]. However, our results showed that although p38 MAPK was phosphorylated in HT-29 cells, no clear interaction with the inflammatory re- 
Total

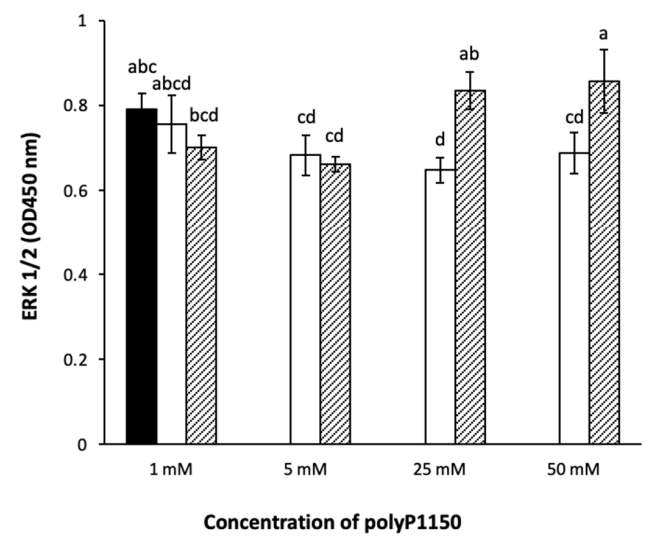

Total

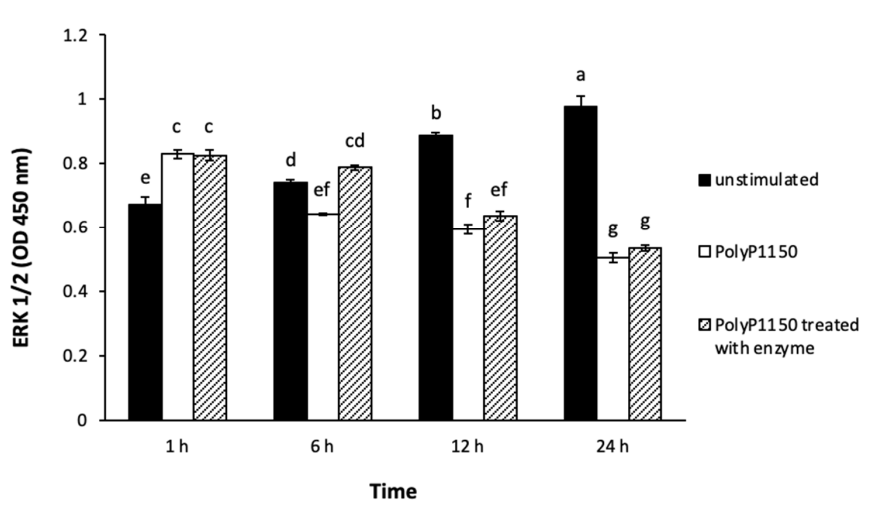

(b)

(a)
Phospho

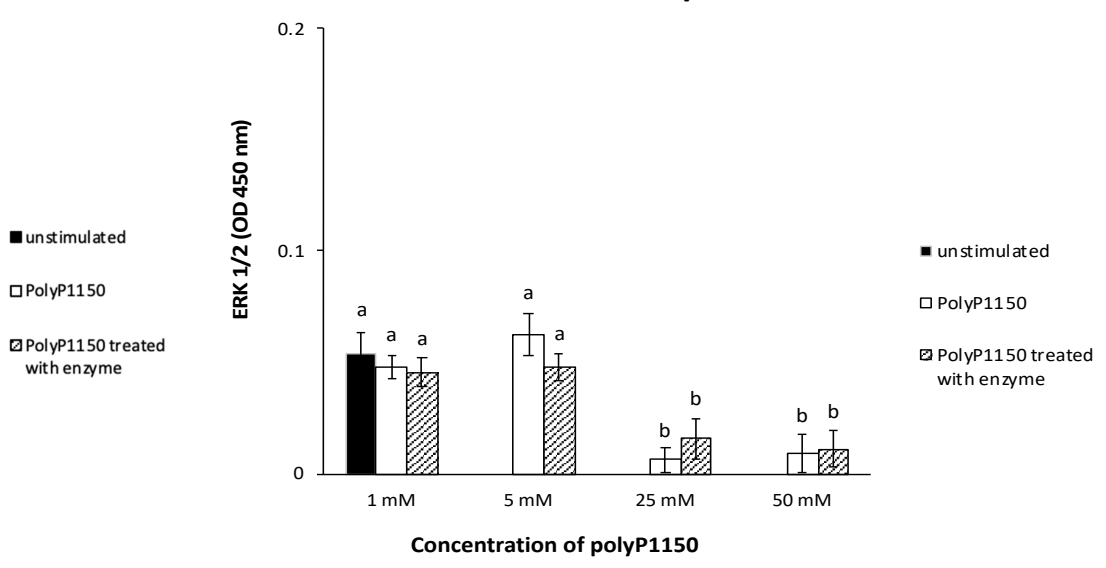

Phospho

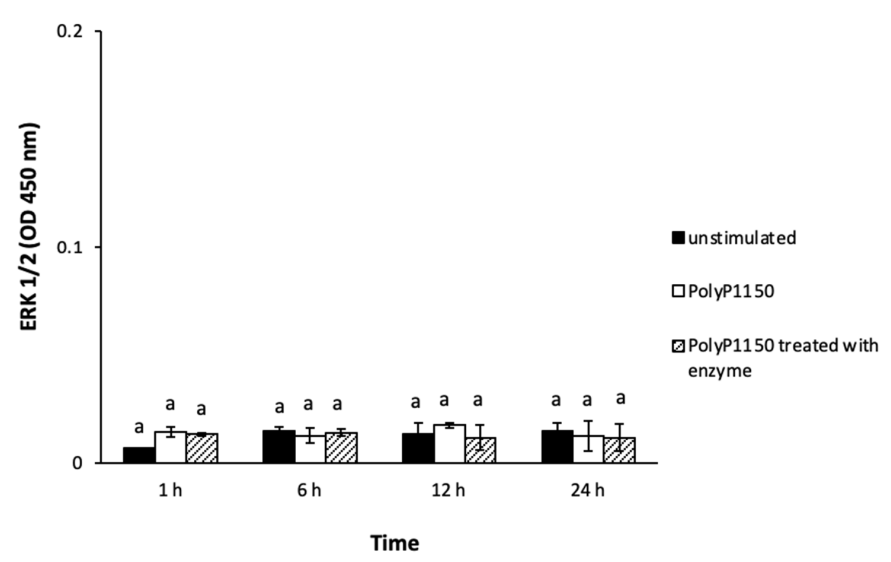

Figure 6. (a) Effect of various concentrations of long-chain inorganic polyphosphates treated with wheat phytase on total/phospho ERK $1 / 2$ activity in HT-29 cells. (b) Effect of long-chain inorganic polyphosphate $(50 \mathrm{mM})$ treated with wheat phytase for different times on total/phospho ERK $1 / 2$ activity in HT-29 cells. Data were presented as mean and standard errors from three experiments. ${ }^{a-g}$ Means lacking common superscripts differ significantly $(p<0.05)$.

sponses caused by polyP1150 was seen. And there was no interaction between ERK and the activation of IL-8/NF- $\mathrm{KB}$ stimulated by polyP1150 in HT-29 cells. In a previous report, TNF- $\alpha$-induced IL-8 secretion in HT-29 cells was mediated via the activation of ERK and p38, independent of NF- $\mathrm{BB}$ [28]. In contrast, in human airway epithelial cells, TNF- $\alpha-$ induced IL- 8 secretion was regulated by NF- $\mathrm{kB}$, independent of ERK [29].

The immune-regulating supplements currently used in animal husbandry to control bacterial polyP substances that cause destructive inflammation, do not act directly on the immune-stimulating mechanism of polyP. But, based on this study, the natural substance wheat phytase may regulate polyP1150-induced IL- 8 release in HT-29 cells by NF- $\kappa$ B, independent of MAPKs such as p38 and ERK. And the implication of these findings is that wheat phytase can act directly on polyP and effectively inhibit pro-inflammatory responses. Therefore, this suggests that wheat phytase has the potential to regulate inflammatory disease caused by bacterial polyP, extending beyond nutritional effects in animal husbandry. Furthermore, wheat phytase may be a promising agent to safely modulate the excessive immune reaction of cells at the cellular level as an anti-inflammatory therapeutic supplement.

\section{CONFLICT OF INTEREST}

We certify that there is no conflict of interest with any financial organization regarding the material discussed in the manuscript. 


\section{FUNDING}

This research was supported by the Basic Science Research Program through the National Research Foundation of Korea (NRF) funded by the Ministry of Education (2017R1D1A1B 03028091).

\section{REFERENCES}

1. Kumar A, Gangaiah D, Torrelles JB, Rajashekara G. Polyphosphate and associated enzymes as global regulators of stress response and virulence in Campylobacter jejuni. World J Gastroenterol 2016;22:7402-14. https://doi.org/10.3748/wjg. v22.i33.7402

2. Pokhrel A, Lingo JC, Wolschendorf F, Gray MJ. Assaying for inorganic polyphosphate in bacteria. J Vis Exp 2019;143: e58818. https://doi.org/10.3791/58818

3. Pina-Mimbela R, Madrid JA, Kumar A, Torrelles JB, Rajashekara G. Polyphosphate kinases modulate Campylobacter jejuni outer membrane constituents and alter its capacity to invade and survive in intestinal epithelial cells in vitro. Emerg Microbes Infect 2015;4:e77. https://doi.org/10.1038/emi. 2015.77

4. Roewe J, Stavrides G, Strueve M, et al. Bacterial polyphosphates interfere with the innate host defense to infection. Nat Commun 2020;11:4035. https://doi.org/10.1038/s41467-02017639-x

5. An J, Cho J. Potential immune-modulatory effects of wheat phytase on the performance of a mouse macrophage cell line, Raw 264.7, exposed to long-chain inorganic polyphosphate. Anim Biosci 2021;34:463-70. https://doi.org/10.5713/ajas.20. 0060

6. Suess PM, Chinea LE, Pilling D, Gomer RH. Extracellular polyphosphate promotes macrophage and fibrocyte differentiation, inhibits leukocyte proliferation, and acts as a chemotactic agent for neutrophils. J Immunol 2019;203:493-9. https:// doi.org/10.4049/jimmunol.1801559

7. Lui EL, Ao CK, Li L, Khong ML, Tanner JA. Inorganic polyphosphate triggers upregulation of interleukin 11 in human osteoblast-like SaOS-2 cells. Biochem Biophys Res Commun 2016;479:766-71. https://doi.org/10.1016/j.bbrc.2016.09.137

8. Hickey TE, Baqar S, Bourgeois AL, Ewing CP, Guerry P. Campylobacter jejuni-stimulated secretion of interleukin-8 by INT407 cells. Infect Immun 1999;67:88-93. https://doi. org/10.1128/LAI.67.1.88-93.1999

9. Bae JS, Lee W, Rezaie AR. Polyphosphate elicits pro-inflammatory responses that are counteracted by activated protein $\mathrm{C}$ in both cellular and animal models. J Thromb Haemost 2012;10:1145-51. https://doi.org/10.1111/j.1538-7836.2012. 04671.x

10. Dinarvand P, Hassanian SM, Qureshi SH, et al. Polyphosphate amplifies proinflammatory responses of nuclear proteins through interaction with receptor for advanced glycation end products and P2Y1 purinergic receptor. Blood 2014;123: 935-45. https://doi.org/10.1182/blood-2013-09-529602

11. Mori N, Oishi K, Sar B, et al. Essential role of transcription factor nuclear factor-kappaB in regulation of interleukin-8 gene expression by nitrite reductase from Pseudomonas aeruginosa in respiratory epithelial cells. Infect Immun 1999; 67:3872-8. https://doi.org/10.1128/IAI.67.8.3872-3878.1999

12. Elliott CL, Allport VC, Loudon JAZ, Wu GD, Bennett PR. Nuclear factor-kappa B is essential for up-regulation of interleukin-8 expression in human amnion and cervical epithelial cells. Mol Hum Reprod 2001;7:787-90. https://doi.org/10. 1093/molehr/7.8.787

13. Chung J, Ku SK, Lee S, Bae JS. Suppressive effects of lysozyme on polyphosphate-mediated vascular inflammatory responses. Biochem Biophys Res Commun 2016;474:715-21. https://doi. org/10.1016/j.bbrc.2016.05.016

14. He W, Zhang Y, Zhang J, et al. Cytidine-phosphate-guanosine oligonucleotides induce interleukin-8 production through activation of TLR9, MyD88, NF-kappaB, and ERK pathways in odontoblast cells. J Endod 2012;38:780-5. https://doi.org/ 10.1016/j.joen.2012.02.026

15. Schulze-Osthoff K, Ferrari D, Riehemann K, Wesselborg S. Regulation of NF-kappa B activation by MAP kinase cascades. Immunobiology 1997;198:35-49. https://doi.org/10.1016/ s0171-2985(97)80025-3

16. Xie H, Newberry L, Clark FD, et al. Changes in serum ovotransferrin levels in chickens with experimentally induced inflammation and diseases. Avian Dis 2002;46:122-31. https:// doi.org/10.1637/0005-2086(2002)046[0122:CISOLI]2.0.CO;2

17. Fairbrother JM, Nadeau E, Gyles CL. Escherichia coli in postweaning diarrhea in pigs: an update on bacterial types, pathogenesis, and prevention strategies. Anim Health Res Rev 2005;6:17-39. https://doi.org/10.1079/ahr2005105

18. Madsen CK, Brinch-Pedersen H. Molecular advances on phytases in barley and wheat. Int J Mol Sci 2019;20:2459. https://doi.org/10.3390/ijms20102459

19. Dionisio G, Holm PB, Brinch-Pedersen H. Wheat (Triticum aestivum L.) and barley (Hordeum vulgare L.) multiple inositol polyphosphate phosphatases (MINPPs) are phytases expressed during grain filling and germination. Plant Biotechnol J 2007; 5:325-38. https://doi.org/10.1111/j.1467-7652.2007.00244.x

20. An J, Cho J. Catalytic properties of wheat phytase that favorably degrades long-chain inorganic polyphosphate. Asian-Australas J Anim Sci 2020;33:127-31. https://doi.org/10.5713/ajas.19. 0047

21. Smith SA, Choi SH, Collins JN, et al. Inhibition of polyphosphate as a novel strategy for preventing thrombosis and inflammation. Blood 2012;120:5103-10. https://doi.org/10.1182/ blood-2012-07-444935

22. O'Sullivan MJ, Hirota N, Martin JG. Sphingosine 1-phosphate (S1P) induced interleukin-8 (IL-8) release is mediated by 
S1P receptor 2 and nuclear factor kappaB in BEAS-2B cells. PloS one 2014;9:e95566. https://doi.org/10.1371/journal.pone. 0095566

23. Zhang Q, Lenardo MJ, Baltimore D. 30 Years of NF-kappaB: A blossoming of relevance to human pathobiology. Cell 2017; 168:37-57. https://doi.org/10.1016/j.cell.2016.12.012

24. Ackermann LW, Denning GM. Nuclear factor-kappaB contributes to interleukin-4- and interferon-dependent polymeric immunoglobulin receptor expression in human intestinal epithelial cells. Immunology 2004;111:75-85. https://doi.org/ 10.1111/j.1365-2567.2004.01773.x

25. Ren T, Qiu Y, Wu W, et al. Activation of adenosine A3 receptor alleviates TNF-alpha-induced inflammation through inhibition of the NF-kappaB signaling pathway in human colonic epithelial cells. Mediators Inflamm 2014;2014:818251. https:// doi.org/10.1155/2014/818251
26. Chai W, Zhang J, Duan Y, et al. Pseudomonas pyocyanin stimulates IL-8 expression through MAPK and NF-kappaB pathways in differentiated U937 cells. BMC Microbiol 2014; 14:26. https://doi.org/10.1186/1471-2180-14-26

27. Bogucka K, Pompaiah M, Marini F, et al. ERK3/MAPK6 controls IL-8 production and chemotaxis. eLife 2020;9:e52511. https://doi.org/10.7554/eLife.52511

28. Jijon HB, Panenka WJ, Madsen KL, Parsons HG. MAP kinases contribute to IL-8 secretion by intestinal epithelial cells via a posttranscriptional mechanism. Am J Physiol Cell Physiol 2002;283:C31-41. https://doi.org/10.1152/ajpcell.00113.2001

29. Li J, Kartha S, Iasvovskaia S, et al. Regulation of human airway epithelial cell IL-8 expression by MAP kinases. Am J Physiol Lung Cell Mol Physiol 2002;283:L690-9. https://doi.org/10. 1152/ajplung.00060.2002 